\title{
Los jurados populares en la administración de justicia en México en el siglo XIX
}

Antonio Padilla Arroyo*

UNIVERSIDAD AUTÓNOMA DEL ESTADO DE MORELOS

El presente texto examina una institución judicial, el juicio por jurados. Esta institución tuvo una vida azarosa y llena

de vicisitudes durante el siglo XIX. Asimismo, se revisan sus efectos dentro del sistema de administración de justicia en México, así como los mecanismos de funcionamiento, las distintas reformas por las que atravesó y se evalúan los debates e ideas que en torno a ella se realizaron.

"La ley no toma en cuenta a los jurados los medios por los cuales han formado su convicción. Sólo les manda interrogarse conforme a su conciencia sobre si el acusado es culpable o no del delito que se le imputa." Admonición escrita que se ponía a la vista de los jurados. ${ }^{1}$

\section{INTRODUCCIÓN}

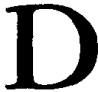
esde los primeros años de vida independiente hasta finales de la década de los veinte del

'Sodi, Memorias, 1961, p. 29. siglo Xx, se abrió un intenso, prolongado $y$, en ocasiones, áspero debate en torno de la conveniencia de instituir los jurados populares $y$, en consecuencia, sobre las limitaciones y los obstáculos que su práctica conllevaba, y de su trascendencia como instrumento para impartir justicia dentro del sistema judicial del moderno Estado mexicano. Prácticamente no hubo etapa de la vida política y judicial de México en el siglo XIX en la que no se hiciera referencia a su utilidad y su conveniencia. ${ }^{2}$

\footnotetext{
${ }^{2}$ En términos formales se puede definir al jurado popular como un juez lego o tribunal
} 


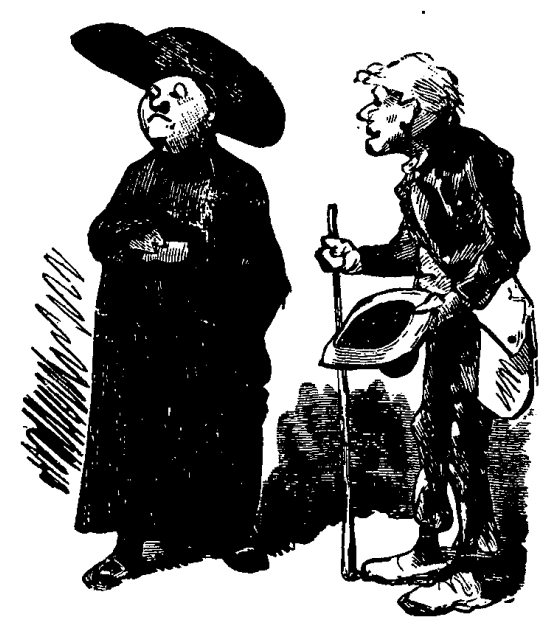

Tanto sus apologistas como sus impugnadores esgrimieron un conjunto de argumentos alrededor de las posibles ventajas o perjuicios que su establecimiento tendría para el país. Uno de ellos, tal vez el de mayor importancia porque estimuló múltiples reflexiones en uno u otro sentido, fue el influjo que podría tener el juicio de jurados en la formación de los ciudadanos y del Estado al ser considerada una de las instituciones centrales para educar al pueblo en las prácticas y los ejerci-

compuesto por personas ignorantes del derecho y poco penetrados acerca del sentido de las obligaciones y derechos de impartir justicia. Es un tribunal que se integra por personas convocadas ex profeso y cuyos miembros son resultado de un sorteo para resolver sobre cuestiones de hecho. En materia penal su veredicto se reduce a declarar "inocente o culpable". Véase Díaz de León, Diccionario, 1986, t. 1, p. 1002. cios de la democracia. Esta idea se inspiró en gran medida en el pensamiento ilustrado, el cual sostenía que esa institución representaba una forma de soberanía popular, era una garantía de participación del pueblo y un mecanismo para asegurar la plena igualdad de los ciudadanos ante la ley y recibir, por tanto, una pronta e imparcial administración de justicia. ${ }^{3}$

El marco en que se abrió la polémica en torno a esta institución judicial fue el periodo de transición de la colonia a la independencia. Como lo ha documentado Linda Arnold, dicho tránsito fue complejo, lleno de tropiezos y dificultades propias de la formación del nuevo Estado, entre ellas las relativas a cuáles serían las características del régimen político y el lugar que habría de tener el poder judicial como parte del mismo, las resistencias de las elites políticas para establecer un poder judicial independiente, nacidas de la desconfianza que les inspiraba la enorme concentración de funciones y atribuciones del aparato judicial colonial y la inter-

\footnotetext{
${ }^{3}$ En particular dos de los principales exponentes de este pensamiento, Cesare Beccaria y Montesquieu, demandaban una reforma profunda, tanto en la legislación penal como en las instituciones y las prácticas judiciales, que incluía la creación de jurados populares. Beccaria fue en especial uno de los más entusiastas defensores de los jurados populares. En su célebre libro De los delitos y las penas hizo una apología de la institución, mientras que Montesquieu en su no menos influyente texto $\mathrm{El}$ espíritu de las leyes destacó sus virtudes para preparar al pueblo en el ejercicio de sus derechos ciudadanos y de escuela para la democracia, aunque se mantuvo cauto al guardar ciertas reservas por los posibles errores en que pudieran incurrir sus integrantes.
} 
vención de los Estados en la administración de justicia. ${ }^{4}$

Paradójicamente, esos factores no hicieron sino acentuar la herencia y el peso del aparato colonial, que extendió su influencia a lo largo del siglo XIX y que con sus inercias entorpeció la creación y organización de instituciones judiciales más apropiadas a las realidades políticas y judiciales de la nación, dejando sus secuelas en las formas $y$ las percepciones sobre la aplicación de la justicia. Ello no quiere decir que todo hubiese permanecido igual, sino más bien que hubo una convivencia entre antiguos y nuevos modos de concebir e impartir justicia. Para Beatriz Urías Horcasitas, el proceso de transición comprendió los años que van de 1821 a 1871, y se caracterizó, entre otros cosas, por la desintegración del antiguo orden jurídico y la configuración de uno nuevo, provocando una situación intermedia en la que por igual se utilizaban las viejas prácticas de administrar justicia, se aplicaba la legislación penal novohispana y los decretos promulgados por los diferentes congresos, nacionales o estatales, y por la escasez de funcionarios judiciales menores para integrar un sistema de juzgados en toda la república y las dificultades para profesionalizar en los niveles inferiores a los jueces, quienes durante el régimen colonial habían sido legos y no letrados, así como por la combinación de nuevos y viejos valores sobre el significado y la naturaleza de la ley, la definición del papel de los funcionarios judiciales $y$, finalmente, por la definición de los crite-

\footnotetext{
Arnold, Burocracia, 1991, pp. 95-126.
}

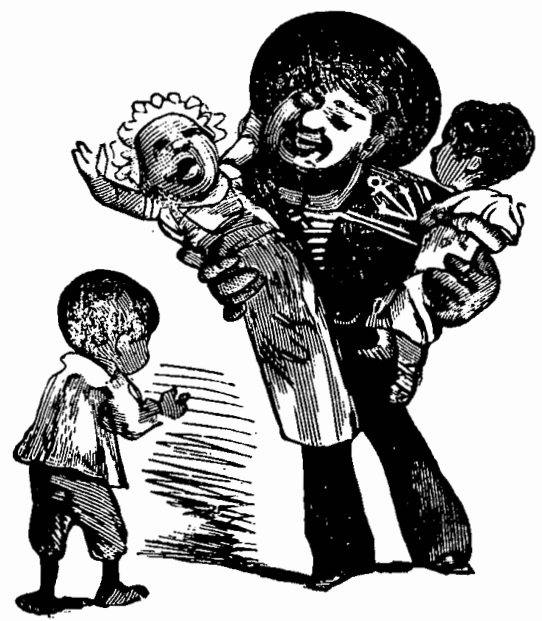

rios utilizados por los jueces para emitir sentencias. De ahí que el tema de la administración de la justicia ocupara un lugar central en los debates en el Congreso nacional, en los congresos estatales y en influyentes sectores de la opinión pública. ${ }^{5}$

\section{UNA INSTITUCIÓN MODERNA}

La obra de Santiago Jonama, De la prueba por jurado o sea consejo de bombres, se publicó justo en el momento en que los estados de la federación se ocupaban de formar las leyes que regularían el nacimiento y el desarrollo del poder judicial y con ello garantizar que la igualdad ante la ley fuera efectiva y no sólo formal, según lo estipulaba "nuestro sagrado códi-

\footnotetext{
5 Urías, "Individuo", 1997, pp. 643-644.
} 
go". En ella, el autor destacó la necesidad de forjar nuevas instituciones que sentaran las bases para un nuevo sistema de justicia. En este sentido, presentó varias consideraciones para alcanzar tal propósito, las cuales serían fuente de controversias a lo largo del siglo XIX.

La primera se refería a "la gran cuestión" de si convenía o no para "la más recta e imparcial administración de justicia" la implantación de esa institución. La segunda hacía referencia al ámbito de sus competencias, es decir, si éstos debían reducirse a conocer y pronunciarse sólo en las causas criminales o también en causas civiles, "como se verifica en Francia", y la tercera, si era deseable que sólo se establecieran en los lugares de mayor ilustración, como era la pretensión de la Comisión de Legislación del Soberano Congreso del Estado de México. ${ }^{6}$ Jonama respondió en forma afirmativa al ser un partidario de los jurados populares, así como de que éstos conocieran y resolvieran tanto en el caso de juicios en materia criminal como de civiles. Alegaba que esa institución, en una severa crítica a los modos y las prácticas de impartir justicia y a las concepciones consustanciales a la administración de justicia colonial, limitaría la facultad de los jueces de juzgar e impartir justicia en forma discrecional, esto es, interpretar la ley de acuerdo con las circunstancias en que se había cometido la infracción, las características sociales del infractor $y$, con base en unas y otras, juzgar cada caso en particular, apoyado en el enfoque casuista, antes que en el

\footnotetext{
${ }^{6}$ Jonama, Prueba, 1824, pp. III-v.
}

apego formal al texto de la ley, pero, sobre todo, pondría fin a lo que estimaba común encontrar, al magistrado "capaz de condenar a un hombre a muerte por complacer al que mande", en tanto que era habitual que los jueces "cargarán más o menos la mano a un pobre acusado para dar gusto a un poderoso". ${ }^{7}$

En este mismo orden de ideas, agregaba otros dos factores legados de las anteriores ideas y modos de administrar justicia. El primero, el carácter permanente de los jueces, lo que provocaba situaciones adversas para el ejercicio de una recta e imparcial aplicación de la justicia. El autor describía con gran agudeza el ambiente social y político que originaba tal situación de este modo:

Estos jueces son permanentes, por consiguiente muy conocidos, tienen mil relaciones en la sociedad, la seducción

${ }^{7}$ El sistema penal castellano, que inspiro la práctica del sistema judicial en el México colonial, según Francisco Tomás y Valiente, en su obra El derecho penal de la monarquía absolu$t a$, se caracterizó por la falta de imparcialidad del juez, la orientación de pruebas hacia la condena, la inferioridad procesal del reo, la reducción de las garantías procesales probatorias de la culpabilidad y el excesivo margen de arbitrio judicial. Tomás y Valiente citado en Urías, "Individuo", 1997, p. 635. Urías apunta que la crítica a las prácticas de impartir la justicia se originó en las corrientes humanistas y racionalistas de fines del siglo XVII y principios del XIX con el objetivo de poner fin, por un lado, al arbitrio y discrecionalidad de los jueces, estableciendo márgenes de acción muy acotados, los cuales deberian sujetarse estrictamente a la ley y, por el otro, garantizando ciertos derechos a los acusados como la presunción de inocencia y el derecho de defensa. 
los cercará por todas partes, lo que no logre el oro, lo conseguirá tal vez el llanto, lo que resista el poder no se resistirá tal vez a la amistad. ${ }^{8}$

El segundo era relativo a que si bien los jueces podían oponer resistencias a ese ambiente, no sucedía lo mismo con la práctica frecuente de impartir justicia, sobre todo en materia criminal, porque su continuo ejercicio los hacía propensos a endurecer su corazón, "haciéndolos orgullos, crueles e insensibles" y, por tanto, a desviarse de su recta actuación. De hecho, era un asunto incontrovertible que los hábitos arraigados en el ejercicio judicial habían propiciado abusos y arbitrariedades en los procesos civiles $\mathrm{y}$, especialmente, en los criminales. ${ }^{9}$

Por todos estos factores, los jurados populares contribuirian a resolver esos problemas al representar un poderoso recurso para mejorar la administración de justicia, evitando que los encargados de aplicarla recurrieran a mecanismos inhumanos que inducían a los acusados a rendirse ante ellos, como por ejemplo, admitir la confesión del acusado sin más consideraciones que haberla obtenido en condiciones desfavorables para él, tales como la insalubridad del calabozo, la melancolía y el abatimiento por la incomunicación, conduciendo al hombre "al suicidio legal que adrede preparan", que servía de base para decidir sobre la culpabilidad del acusado y la imposición de la pena, en lugar de conseguir la "prueba legal", lo que en la práctica era una ne-

\footnotetext{
8 Jonama, Prueba, 1824, pp. 5-6.
}

Ibid., p. 7. gación de las garantías que todo acusado debería de tener. ${ }^{10}$

Para Jonama no había duda de que la nación estaba preparada para asumir esa responsabilidad porque las virtudes y cualidades que demandaba esa institución judicial, tales como "razón natural, madurez e independencia personal", estaban presentes en una gran franja de la población, esto es, entre los propietarios. De este modo, el autor señalaba que era un error interpretar en forma literal la idea de quiénes debían integrar los jurados populares, es decir, los pares, porque "imaginar que el crimen de un jornalero ha de ser juzgado por otro jornalero" no correspondía exactamente a su sentido legal, pues el par "quiere decir iguales ante la ley". Así, la práctica de los jurados debía circunscribirse al sector de propietarios porque, según explicaba, sus miembros eran los más interesados en mantener el orden "no sólo por el deseo de conservar sus propiedades", sino porque éstas eran la base de "todos los demás derechos civiles". En suma, Jonama estimaba que no eran válidos los alegatos que se esgrimían para oponerse a esta institución, como la falta de ilustración entre las clases bajas o su falta de firmeza de ánimo para resistir los ruegos, las amenazas y "todos aquellos medios de seducción que se emplearan". Por eso no era indispensable poseer "el estudio de las leyes", cuya falta no debía "causarnos temor". 11

No se sabe con exactitud si las observaciones y las recomendaciones de Jonama en torno al jurado popular tu.

${ }^{10}$ Ibid., pp. 9-10.

1 Ibid., pp. 27-34. 
vieron alguna influencia en las autoridades políticas y judiciales, pero sí que se instalaron y que funcionaron los juicios por jurados para conocer de diversos delitos durante el siglo XIX y las primeras décadas del Xx. La historia de los jurados populares en el país da cuenta de su funcionamiento en materias tan disímbolas como delitos de imprenta, delitos comunes y delitos oficiales. Los primeros jurados se orientaron a juzgar los delitos de imprenta.

La aclimatación de los jurados populares en el país también moldeó parte de las preocupaciones de preceptores y filántropos, quienes pensaban que su instauración contribuiría a forjar buenos ciudadanos. Al menos esta fue la idea que expresó el francés Estevan Guenot, avecindado en la ciudad de Toluca, en su Plan de educación elemental y de varios establecimientos de utilidad pública y de beneficencia. Tras solicitar el auxilio del Congreso de la Unión, expuso que en su proyecto estaba considerado poner en marcha, dentro de los planteles escolares que fundaria, un sistema de premios y castigos, incluyendo el juicio por jurados para castigar los delitos graves. Guenot explicaba de la siguiente manera su propuesta:

Para los delitos graves instituyo un jury que se compone de doce discípulos escogidos entre los que están reconocidos por más fieles a sus deberes clásicos y religiosos. El director no hace más que exponer el delito; el acusado se defiende después ya por sí mismo, o por el órgano de uno de los monitores generales, y terminados los debates, los jurados se retiran para deliberar con entera libertad. Confirmado su juicio por el inspector de la escuela, es ejecutado puntualmente. El niño declarado culpable es castigado conforme a las disposiciones del código penal de la escuela.

Según Guenot, la experiencia en estas prácticas judiciales y de aplicación de la justicia había demostrado que "[en los niños] la razón es mas precoz de lo que comúnmente se cree", lo que modificaba la percepción generalizada de que los infantes eran incapaces de discernimiento. En suma, sostenía el preceptor, en esta modalidad de jurado los niños se familiarizaban "desde sus mas tiernos años con los principios eternos de la justicia", y su continua aplicación los inducía "a respetarla y a arreglar a ella su conducta". ${ }^{12}$

Por su parte, el polémico escritor y político Lorenzo de Zavala también compartía la opinión de Guenot en el sentido de que la creación de los jurados populares podía estimular la educación popular y, por añadidura, la formación de los ciudadanos. Zavala consideraba que tanto la libertad de imprenta como los juicios por jurados en las materias de imprenta, la asistencia a los debates de las cámaras y asambleas legislativas, las juntas electorales "y otros actos igualmente originados en los cambios hechos después de la independencia", eran elementos que permitirían la formación entre los mexicanos de un "nuevo espíritu público", e insistía en que mediante ellos se aprenderían nuevos hábitos y costumbres de convivencia social que, a su vez, tendrían efectos favorables en la

${ }^{12}$ Guenot, Plan, 1826, pp. 19-20. 
administración, al exigir de los jueces y magistrados nuevas formas de comportamiento en la impartición de justicia.

Particularmente, recomendaba su adopción inmediata con el propósito de mejorar la imagen que de los jueces y de los tribunales tenía el pueblo, acostumbrado a ver en ellos "instrumentos de la tiranía". Según Zavala, la situación de la procuración y la administración de justicia tanto en materia criminal como civil era tal que se habían "casi extinguido los efectos que deben producir sobre su moralidad los ejemplos saludables de la justicia". El cuadro que dibujó era desconsolador:

Presentado el mexicano delante de una autoridad que no era responsable de sus acciones, que no estaba sometida a ninguna ley, y entre las que no era raro contar algunos que no conocían ni aun las del honor, se creía rodeado a todas horas de delatores, espías o agentes provocadores. No pudiendo encontrar una garantía suficiente en el testimonio de su conciencia, se veían obligados los habitantes a tomar hábitos de disimulo, de adulación y de bajeza. Ya no se consideraba el castigo como consecuencia de los delitos; y los suplicios vinieron a ser a sus ojos como las enfermedades, una calamidad inherente a la naturaleza, de manera que el temor de sufrirlos no los detenía en la carrera del crimen. ${ }^{13}$

Zavala se expresaba en términos muy similares a los de Jonama en relación con las prácticas con las que actuaban los jueces y los tribunales, es decir, la discrecionalidad y las amplias facultades que la ley les otorgaba, en-

${ }^{13}$ Zavala, Ensayo, 1985, pp. 294-295. tre ellas la formación del proceso, el interrogatorio a los testigos y la imposibilidad de la defensa oral de los acusados y el temido procedimiento de "el secreto del gabinete". Por ello, el pueblo se había acostumbrado a ver en la justicia, en particular la criminal, "un poder perseguidor y odioso" $y$, en contraste, despertaba en él una reacción natural de enorme simpatía y protección que los delincuentes e infractores disfrutaban, lo que originaba que se sustrajeran a la acción de las leyes, librando, "como ellos se explican, a los pobres de las garras de la justicia".

Según sostenía Zavala, la situación de la justicia era lamentable debido en gran medida a la conducta equívoca de los órganos responsables de su aplicación, al percibirse en los jueces una "nota de infamia". El diagnóstico era concluyente:

Esta liga contra la justicia criminal está formada en muchos lugares de la república, y tiene su origen en las pasadas injusticias, en la confusión con que han sido juzgados los criminales y los desgraciados que han pertenecido a un partido vencido, en la manera secreta de formar los procesos, y en la escandalosa detención de las sentencias de reos de los mas feroces crimenes.

Agregaba que si en algún lugar de la república era posible tener un cuadro completo en materia de justicia como el descrito, ese lugar era la ciudad de México, donde se "había desplegado toda la chicana judicial", es decir, donde se acentuaban los males de una legislación criminal y civil llena de contradicciones y recovecos que habían acabado por levantar "una barrera a la 
sencilla acción de las leyes, en donde el oro, el favor, la intriga y el poder", se empleaban alternativamente, "o a la vez, en oscurecer la justicia y elevar el imperio de la fuerza sobre la ruina de las leyes". ${ }^{14}$

Para subsanar en lo posible esta situación y enmendar los errores más evidentes de esas prácticas, Zavala presentó en 1826 un proyecto de ley sobre el establecimiento de los jurados populares, aunque reconocía que éste había encontrado serias resistencias por parte de "aquellos legistas que encuentran, en los vicios de las leyes, elementos de existencia, su reputación y sus clientelas". En su alegato sostenía que no podía haber una correcta administración de la justicia mientras no se reformaran las legislaciones tanto en materia criminal como civil que garantizaran poner a salvo la integridad de los ciudadanos y sus bienes, así como imponer castigos ejemplares a los criminales.

Según Zavala, los juicios por jurados eran "una grande escuela de moral para los asistentes", tenían un efecto pedagógico entre el pueblo porque su práctica cotidiana le brindaría los ejemplos y los auxilios necesarios para evitar que los individuos cayeran en "las tentaciones violentas" que los rodeaban, inhibiendo los estímulos que los conducían a la comisión de delitos, recibirían lecciones de buen comportamiento al ser testigos de los debates, los veredictos y la exposición de la destre$\mathrm{za}$, de las habilidades y de los conocimientos de los jueces para descubrir los crímenes mediante "una serie de

${ }^{14}$ Ibid. circunstancias imprevistas", exhibiendo "la conciencia perturbada del culpable [que] es su primer acusador, y que ningún goce han proporcionado estos crímenes que parecían llenar los deseos de sus tristes ejecutores" y, finalmente, coronar con éxito la labor de la justicia al aplicar la pena.

De igual modo, otro efecto benéfico de la institución judicial sería que los jueces estarían obligados a actuar con absoluta imparcialidad en la medida en que éstos se asumirían como auténticos representantes del orden social, de su conservación, con un criterio ilustrado al imponer una pena después de haber demostrado plenamente el crimen. De esta manera, tanto los integrantes del jurado, el corazón, como los tribunales, el juicio, se unirian de forma natural convencidos mutuamente de la justicia y la integridad con la que habrían actuado, abandonando, "sin pesadumbre, al culpable al rigor de las leyes". ${ }^{15}$

Por su lado, en marzo de 1827 José María Luis Mora también formuló un conjunto de reflexiones en torno a las ventajas de instituir el juicio por jurados como parte de las instituciones del sistema de administración de justicia en materia criminal. Al igual que Zavala y Jonama, Mora señalaba que sin esta institución no era factible tener un mecanismo que limitara la enorme autonomía de los jueces, pero, a diferencia de aquéllos, presentaba una situación inversa, la posibilidad de que los intereses del delincuente coincidieran con los del juez encargado de enjuiciarlo y, por añadidura, no actuara

${ }^{15}$ Ibid. 
en defensa de los intereses legítimos de la sociedad. En efecto, a la luz de las experiencias que habían arrojado los juicios de libertad de imprenta, no dejaba de expresar un moderado optimismo sobre los jurados populares, pero consideraba que aun y cuando la experiencia hubiera demostrado inconvenientes, destacaba que presentaba más virtudes que defectos.

Para Mora, los problemas que había presentado su práctica se debían sobre todo a la falta de claridad en la legislación que los reglamentaba, e insistía en que lo que el país requería era

una reforma verdadera, simplificando las leyes de procedimientos y poniendo a cargo de diversas autoridades la decisión de las cuestiones de hecho y de derecho o, lo que es lo mismo, la declaración de los hechos y la aplicación de las leyes. ${ }^{16}$

Reconocía que el defecto principal del juicio por jurados había sido su organización interna, en tanto que los que hasta ese momento se habían encargado de juzgar los casos de la violación al reglamento de imprenta no habían cumplido con los requisitos de honestidad, rectitud e imparcialidad inherentes a la institución, alterando su propia naturaleza, pues "si a semejante reunión de hombres se hubiera de confiar la decisión de los puntos de hecho en el orden judicial", la persecución se desataría de un modo legal en contra del pacífico habitante, "contra el virtuoso ciudadano que, lejos de las intrigas y enredos de los partidos,

${ }^{16}$ Mora, Disertación, 1986, p. 246. los despreciase a todos y no secundase las miras torcidas de ninguno; mas no es éste el jurado del que yo hablo". ${ }^{17}$

En tal tesitura se preguntaba: " $i Y$ dónde podrá hallarse con más seguridad [la imparcialidad en la aplicación de justicia] que en el jurado?" La respuesta era evidente: en la unión de hombres cuyo único propósito era hacer cumplir la ley sin estar atados a otro tipo de circunstancias e intereses, haciéndolos compartir intereses comunes y girando alrededor de impartir una justicia imparcial porque ellos mismos podían encontrarse, por cualquier eventualidad, en el papel de acusados, toda vez que "al día siguiente" podían "convertirse de jueces en reos y verse en la necesidad de dar cuenta de su conducta a sus conciudadanos". La cuestión estaba, según su exposición y con argumentos muy análogos a los de Jonama, en asegurar una selección adecuada de los jurados, quienes no necesariamente requerían tener conocimientos de derecho, es decir, bastaba con poseer

un entendimiento libre $y$ despreocupado, ajeno a toda prevención en favor de doctrinas o sistemas; independencia absoluta de los agentes del gobierno y de todo género de partidos, interés grande en el castigo a los crímenes y en el sostén del orden y tranquilidad pública.

Asimismo, Mora consideraba esencial la concurrencia de otras condiciones a fin de que el juicio por jurados cumpliera en forma cabal con sus funciones: absoluta nitidez en los proce-

${ }^{17}$ Ibid. 
dimientos, correcta elección e integración de los jurados, junto con la capacidad de exposición de los fiscales y la contundencia de los hechos y de las pruebas presentadas por las autoridades. Estaba persuadido de que si éstas se satisfacían, entonces era posible pensar que esta institución fuera la mejor contribución para la formación de los ciudadanos. ${ }^{18}$

Entre las reformas que consideraba pertinentes para fijar con exactitud los procedimientos estaban la de mantener en el anonimato el nombramien. to de los jurados hasta momentos antes de su integración, evitando que pudieran ser sobornados, a lo que se sumaba la presión moral y social de ser propietarios y padres de familia, impidiéndoles la posibilidad de corromperse. En este sentido y según su concepto de democracia censataria, no todos los habitantes reunían las cualidades para integrar los jurados populares. Sólo los propietarios conjugaban virtud y honorabilidad, pues esta clase era "verdaderamente independiente", componiéndose de ciudadanos que de manera natural inspiraban "confianza así al legislador como a la masa de la nación", mientras que el indigente, el jornalero y el deudor "no pueden menos de ser accesibles al soborno cuando su subsistencia, que es la primera necesidad del hombre, depende de aquellos que pueden tener interés en corromperlo". 19

Y si estos argumentos no bastaban para inclinarse por su instauración, existía la circunstancia de que:

${ }^{14}$ Ibid., pp. 249-250.

${ }^{19}$ Ibid., p. 252. el conocimiento de las personas, de sus hábitos y costumbres, de sus vicios y virtudes y de su carácter individual, no pueden estar al alcance de un juez, a quien tratan poco y de quien necesariamente se ocultan, como lo están del de la masa de sus conciudadanos, con quienes necesariamente contraen relaciones que los dan a conocer y manifiestan el grado de probabilidad y certidumbre que debe darse a su testimonio y los motivos que hay para temer que sean actores o cómplices de los crímenes y desórdenes de que son acusados. $^{20}$

Este proceder, según Mora, era el único establecido por la naturaleza y por las leyes humanas para evitar que los delincuentes quedaran impunes. Así, los jueces, peritos en derecho, desempeñarían el "importantísimo" papel de imponer la pena correspondiente que prescribía la ley y, por ende, se estaría en el camino de arraigar una correcta administración de justicia. El autor aclaraba en su extensa y convincente disertación que con ello se lograría el equilibrio imprescindible que habría de existir entre ambas instancias de justicia: "El jurado debe ser un freno para el juez y éste debe serlo para el jurado, en términos de que de la reunión y equilibrio de uno y otro resulte la más perfecta armonía". ${ }^{21}$

Para concluir, Mora presentaba un hecho contundente: la práctica de los jurados había demostrado rectitud y certeza en su actuación, aunque no habían estado exentos de resoluciones erróneas, descartando los temores de

${ }^{20}$ Ibid., p. 250.

${ }^{21}$ Ibid., pp. 250-251. 
quienes se oponían al jurado popular, entre ellos "hombres respetables por sus luces, talentos y práctica constante en los negocios de judicatura", con el argumento "de que aún no estamos en estado de adoptar esta benéfica institución" (cursivas en el original). Sin embargo, recomendaba que los nombramientos de los jurados fueran hechos por mandato expreso de la ley y no por elección, ya que de esta manera se aseguraba no someterse a ningún tipo de intereses, fueran éstos corporativos o personales. Precisamente, gran parte de estas formulaciones serían expuestas por aquellos que defenderían la institución del jurado popular, al precisar la idea exacta del significado de los "pares" en funciones de juzgadores. ${ }^{22}$

Las críticas que se lanzaban contra la administración de justicia no pasaron inavertidas para los magistrados y jueces. De hecho, la incipiente formación de instituciones judiciales que requerían de las nuevas condiciones políticas del país era motivo de cavilaciones para la Suprema Corte de Justicia. Así, en un detallado informe que ésta rindió al poder ejecutivo, reconocía los problemas que se presentaban para una expedita e imparcial procuración de justicia pero, al mismo tiempo, ponían en claro que gran parte de ellos no podían ser atribuidos exclusivamente a incapacidad o negligencia, sobre todo cuando no se había elaborado el nuevo marco jurídico que debía regir en correspondencia con las circunstancias de la nación, y que a pesar de

${ }^{22}$ Ibid, pp. 252-253. esa carencia "jamás se había dejado de administrar justicia". La Suprema Corte resumía las principales dificultades por las que atravesaba la justicia en México:

En conclusión, la nula o mala administración de justicia, tanto en negocios de federación, como en los comunes del Distrito y territorios, de que se babla con tanta generalidad, no reconoce otro origen más que la falta de leyes que arreglen radicalmente este ramo, con la filosofia que corresponde, $y$ conforme al sistema de gobierno de la república (cursivas en el original).

Asimismo destacaba que mientras no hubiera una ley que delimitara el ámbito de competencias entre el poder ejecutivo y el poder judicial, se mantendría éste bajo "el influjo y la autoridad de aquél", sujetándose a sus deseos y recomendaciones. De igual manera, la máxima institución judicial hacía notar que tanto la falta de disposiciones relativas a los tribunales y juzgados como la formación de los códigos en materia civil y criminal, en especial este último, que definiera y clasificara los delitos de los funcionarios y los delitos comunes, hacía imposible modificar las prácticas, los valores y los hábitos $\mathrm{y}$, por tanto, instituir un nuevo sistema de administración de justicia. Es decir, para los magistrados que integraban la Suprema Corte había problemas estructurales, dentro de la administración de justicia, que había que remover si se deseaba reformar el antiguo sistema de justicia. ${ }^{23}$

23 "Informe", 1986, pp. 141-142. 
Durante los debates del Congreso Constituyente de 1856 se deliberó en torno a la conveniencia de establecer los juicios por jurados para conocer de causas en materia civil y penal. Este tema fue uno de los más candentes y polémicos no sólo entre los integrantes de la comisión encargada de redactar el proyecto de Constitución, sino entre todos los representantes populares ante el Congreso al momento de presentarse para su aprobación. En particular para sus partidarios era tal su importancia, que inicialmente incluyeron esta institución como parte de las garantías individuales. De igual modo, sus adversarios presentaron serias dudas sobre su utilidad. La Comisión de Constitución propuso que se instituyeran los juicios por jurados para los delitos del orden común. La presentación del artículo 24, fracción 4a. y su posterior debate, fueron una oportunidad propicia para esbozar la situación de la procuración y administración de justicia a mediados del siglo XIX, la cual, por otro lado, poco se había modificado según los testimonios que habían elaborado tanto Jonama como Mora y Zavala, y aun la propia Suprema Corte de Justicia. Desde la redacción del artículo se suscitaron diferencias notables entre los miembros de la comisión. Éstas se hicieron aún más evidentes en el momento de su presentación formal ante el pleno del Congreso. Como en otras ocasiones, la simple propuesta despertó polémicas arduas entre quienes consideraban fundamental su implantación como garantía constitucional y como institución y práctica dentro de la administración de justicia y de la legislación judicial penal, y sus fervientes opositores.

Por ejemplo, uno de estos últimos, Isidoro Olvera, sostuvo que la institución del juicio por jurados en materia criminal era "enteramente nueva en nuestro país", lo que se demostraba con el hecho de que apenas "uno o dos estados" lo habían introducido en sus prácticas judiciales y sólo "por algún tiempo", dando resultados que no correspondían "a sus esperanzas". Para Olvera, eran varias las razones que ayudaban a comprender por qué no se habían obtenido los frutos que se esperaban de los jurados populares: la inexistencia de una conciencia pública, "que como se sabe, resulta de la identidad o siquiera analogía de las conciencias individuales"; la carencia de moralidad que rigiera las conciencias de sus habitantes $y$, finalmente, la insuficiencia de ilustración pública, sobre todo porque se desconocían ciertos derechos naturales que fundaban la equidad, así como obligaciones y deberes sociales en que se fundamen. taba la justicia. En resumen, para Olvera los habitantes del territorio no reunían ni la instrucción ni las costumbres, así como tampoco las "habitudes [sic] republicanas que hicieran respetar el fallo público". Más aún, existía una realidad social irrefutable: la población era heterogénea por raza, clima e intereses, lo que tenía como consecuencia que no se presentaran dos poblaciones con un mismo grado de moralidad. Así pues, era "demasiado difícil trasplantar al país esta clase de juicio". ${ }^{24}$

${ }^{24}$ Zarco, Historia, 1857, pp. 487-484. 
Bajo esta línea de argumentación, Ignacio Vallarta secundó la posición de Olvera. El primero centró su posición en dos argumentos. Uno de ellos era de naturaleza política, es decir, demostrar que el juicio por jurados no necesariamente era una institución inherente a la democracia y, por tanto, invalidar el alegato que presentaban sus defensores acerca de que ésta fuese producto de la sociedad civil, esto es, que representara la soberanía popular, por lo que su incorporación al código fundamental era una grave intromisión en las formas de organizar la justicia en los estados y una violación inaceptable al pacto federal. El segundo era una postura legal y judicial. Ponía en duda sus bondades como mecanismo para mejorar las prácticas judiciales. En efecto, reconocía que el estado de la justicia, sobre todo en materia criminal, era pésimo, pero lo atribuía en lo fundamental a que el foro estaba todavía empapado tanto de la legislación como de las prácticas judiciales españolas, y mientras una y otras siguieran rigiendo, era imposible introducir los jurados populares, porque esa legislación no despertaba "ni de lejos" la menor simpatía por esa institución, a lo cual se agregaba que muchos abogados y jueces se resistían no sólo a su adopción sino a su ejercicio. Para Vallarta la mejor solución a la situación por la que atravesaba la administración de la justicia era la elección popular de los jueces por el pueblo. ${ }^{25}$

En contraste, los adeptos sostenían argumentos en sentido inverso, es decir, que los juicios por jurados sí eran

${ }^{25}$ Zarco, Crónica, 1957, pp. 499-508. una personificación de la soberanía popular, y aducían que aun si este no fuera el caso, los jurados eran una expresión del Estado moderno, "nacida de ideas y doctrinas, de reformas realizadas en la ciencia del derecho penal y en la legislación procesal criminal en los últimos tiempos", por lo que su establecimiento era una exigencia para la administración de justicia. Uno de los defensores más tenaces, José María Mata, opinaba que los jurados populares precisamente podian enmendar las leyes injustas o sus defectos, pues "al pasar por el crisol del jurado", éste fallaba en nombre de la justicia y de la conciencia, lo cual no sucedía con los jueces, en tanto que no podían salirse del texto de la ley y procedían según las pruebas presentadas, obligándolos a "fallar contra su conciencia". Y en alusión directa a la tesis de Vallarta de la violación del pacto federal, alegaba que entonces todos los derechos y garantías consagrados en la Constitución serían un ataque al sistema federal. ${ }^{26}$

En este sentido, Zarco, tras de presenciar y participar en los debates, no dejó de apuntar, en un tono de ironía y desaliento, que los reparos a la institución revelaban un desconocimiento de la historia de los jurados, y que para suplir esa falta habían "recurrido a dar el nombre de jurados a lo que mejor les ha parecido". Sin embargo, estos argumentos no lograron persuadir a la mayoría de los constituyentes, quienes se pronunciaron, por 42 votos, en contra de su fijación para conocer de delitos comunes, en tanto que 40 votaron a favor. Para quienes creían

${ }^{26}$ Ibid., p. 509. 
en las ventajas de los juicios por jurados no era una batalla menor la resolución que había tomado el pleno del Congreso. De nueva cuenta fue Zarco quien ofreció una estampa del estado de ánimo que rodeaba a los simpatizantes de esta institución:

iOtra batalla perdida! iOtra reforma frus trada! El juicio por jurados fracasó ayer en la Asamblea Constituyente porque no es tiempo de que nuestro pueblo goce de esta garantía. Tal vez lo será cuando todos los ciudadanos sean jurisconsultos. ${ }^{27}$

No obstante, el simple hecho de haber logrado que fuera un punto en las deliberaciones del Constituyente tuvo un valor fundamental, y fue una señal sobre el lugar que podría ocupar dentro de las instituciones judiciales. Más aún, aunque en ese momento no se evaluó como un resultado positivo, se puso en el centro de las reflexiones un emplazamiento a las elites políticas para situar en los primeros lugares de su agenda de innovaciones políticas y judiciales el estado del sistema de administración de justicia y la urgencia de reformarlo casi en su totalidad. Mientras tanto, se habían dibujado apenas en líneas tenues varios elementos que poco tiempo después marcarían el futuro de los jurados populares al ordenarse su establecimiento en el Distrito $\mathrm{y}$ territorios federales.

Paradójicamente, fue Mariano Arizcorreta, crítico de los juicios por jurados, quien trazó algunos aspectos que

${ }^{27}$ Ibid., pp. 499 y 511; Legislación, 1855, pp. $649-650$. serían en el futuro el eje de nuevos debates y reformas en su práctica. Entre ellos las calidades morales, políticas y sociales de sus miembros, así como su funcionamiento. Con respecto a esto último se preguntó si los veredictos pronunciados por los jurados serían inapelables o habría una segunda instancia con funciones de revisora, si habría uno o dos jurados y, si este fuera el caso, qué sucedería en el lance de que sus sentencias fueran contradictorias, y entonces cuál de los dos representaba la conciencia pública. Asimismo, adelantándose a las dificultades que la práctica misma haría resaltar y que también fueron motivo de examen, adelantaba que el jurado tendría que hacer tres calificaciones: la de culpabilidad, que equivaldría a la declaración de haber lugar a la formación de la causa, la del hecho, y la de la ley, lo cual era preciso dilucidar, porque todo proceso criminal conlleva distintas fases y grados en su desarrollo.

De igual modo, Arizcorreta sugirió que en cuanto a las calidades morales era posible esperar que los integrantes de los jurados actuaran en sus deliberaciones con base en un elevado y agudo sentido común, pero en el caso de los veredictos necesariamente se requería contar con un mayor conocimiento de la ciencia y la práctica, más allá del conocimiento del derecho y, por último, sostenía que las habilidades y destrezas para la aplicación de la legislación penal no podía reducirse simplemente a saber leer los códigos, aun cuando éstos fueran sencillos. ${ }^{28}$

${ }^{28}$ Zarco, Crónica, 1957, p. 510. 


\section{IDEAS Y DEBATES}

Como se ha apuntado, la polémica que se suscitó en el Congreso Constituyente con respecto a los jurados populares en materia penal creó un ambiente que favorecería distintas iniciativas para su instauración. La discusión, aunque se atemperó por más de una década, no desapareció del ánimo ni de la voluntad de sus simpatizantes. En la práctica, la polémica se pospuso por razones urgentes, debido a la inestabilidad social y política en que se vio envuelto el país entero, hasta que se logró la tranquilidad, la cual llegaría con la restauración de la república. Los liberales se propusieron de nueva cuenta introducir el debate sobre los jurados populares. El ejecutivo federal promovió una ley que introducía esta institución con atribuciones para conocer y juzgar los delitos comunes, aunque se cuidaba de darle un carácter de obligatoriedad para todos los estados de la república. Es decir, el ámbito de su aplicación sería exclusivamente el Distrito Federal, lo cual reconocía implícitamente las resistencias que se mantenían en el interior del órgano legislativo.

Ya desde 1850 se había presentado y discutido en el Congreso la pertinencia de establecer el juicio por jurados a propósito de la ley para juzgar a los ladrones en el Distrito Federal, por parte de la comisión encargada de elaborar dicha ley, bajo el argumento de "parecerle el único y el más adecuado para atender esta necesidad", porque ello aseguraría acabar con la impunidad de que gozaban los ladrones debido "al vicioso sistema de administración criminal recibido entre nosotros". En esta línea de ideas, la comisión alegaba que era indispensable que no cayera la responsabilidad de procesar y castigar a los autores de este delito en un solo individuo, pues: "El que averigua el autor de un delito no debe ser el mismo que diga a su vez si está o no averiguado, ni, en caso afirmativo, qué pena le corresponda", no sólo porque en él se reunian las figuras de fiscal y de juez, lo que en ambos casos lo obligaba a calificar su trabajo, y en estas condiciones

nadie debe esperar que califique y decida en su misma obra con la imparcialidad debida, sino porque la legislación penal lo obligaba a tomar medidas sumamente severas, $y$ ante tal eventualidad no tenía otra alternativa que, o alargar el curso de la causa, o imponer una pena suave, lo que en la práctica equivalía a la total impunidad de los criminales.

En cambio, el juicio por jurados tenía la virtud de que, al ser integrado por personas de diferentes orígenes sociales y formaciones morales, éstas podian tener mayores elementos para decidir sobre la culpabilidad de un acusado. En este sentido, la comisión redactora estaba consciente de los reparos que se lanzaban a la institución, sobre todo el que hacía referencia a la falta de ilustración en la mayor parte de los estados de la república. Sin embargo, sostenía que tratándose del Distrito Federal no existía tal objeción, pues en éste se encontraba "la parte más selecta de ciudadanos mexicanos, y por tal circunstancia en él debe ensayarse un sistema adoptado por todas las naciones civilizadas de Europa y América". ${ }^{29}$

${ }^{29}$ El Siglo $X I X, 1,2,3$ y 4 de febrero de 1850. 
La iniciativa de ley motivó diversos comentarios de $E l$ Siglo $X I X$, el cual, en extensos artículos, expresó su conformidad por el hecho en sí mismo de haber mostrado su interés para reprimir cierto tipo de delitos, pero no compartió los puntos de vista de los responsables del proyecto ni tampoco mostró simpatías por la creación del juicio por jurados. Recordaba que mientras no se reformara la legislación criminal era impensable que se alcanzara una mayor eficacia en la persecución y el castigo de los crímenes. En cambio, señaló que era necesario avanzar en la reforma criminal en tres sentidos: perseguir eficazmente a los homicidas y ladrones, abreviar los juicios criminales y establecer con toda claridad la penalidad para cada delito. Estas medidas tendrían que venir acompañadas de una reorganización policiaca, la cual incluiría la creación de la policía preventiva. En suma, para los redactores del periódico la iniciativa no consideraba ninguna de estas innovaciones, por lo que estimaba inútil que se discutiera en el Congreso. De igual manera, consideraban, los juicios por jurados en nada cambiarían la actitud de benevolencia con la que procedían los jueces, porque una asamblea era más susceptible de conmiseración y generosidad, y al menos los jueces se encontraban sujetos a la censura de la opinión pública y a responsabilidad legal. ${ }^{30}$

El 19 de febrero se discutió la iniciativa, la cual fue atacada con dureza, sobre todo por parte del diputado Jesús Agraz, quien la rechazó en todos 1850.

${ }^{30}$ El Siglo $X L X, 7,11,13$ y 20 de febrero de sus términos, y no porque se opusiera a la instauración de los juicios por jurado, sino porque estimaba que no había condiciones suficientes para lograr sus objetivos. Entre sus objeciones estaba que no eran ni la época ni la situación del país en general ni del Distrito en particular, las más favorables, por lo que de aprobarse, lejos de extinguir o disminuir el mal no "haría más que aumentarlo". Para Agraz, el principal factor que explicaba el incremento de la criminalidad radicaba no en el proceder y la conducta de los jueces, sino en la falta de una policía preventiva que se encargara de aprehender, así como en la incapacidad para suministrar datos suficientes para demostrar la responsabilidad de los criminales. Así, sin estos elementos fundamentales para garantizar la mejora en la administración de justicia, equé podían hacer no sólo los jueces sino los jurados?, $y$

si los medios de aprehensión y averiguación han de seguir faltando, iserá posible que el jurado, sólo por ser jurado, pueda conseguir la prisión de los delincuentes, y que sin datos pueda fallar con acierto distinguiendo al inocente del culpable?

Para Agraz primero era necesario reformar la legislación penal y establecer una policía preventiva activa y laboriosa que lograra la seguridad del país, desapareciendo de esta manera "los motivos de antipatía con que hoy obraría el jurado", evitando veredictos que se inclinarían por los acusados. Bajo estos argumentos, el Congreso desechó la iniciativa de ley y con ello la posibili- 
dad de establecer los juicios por jurados para delitos del orden común. ${ }^{31}$

Casi dos décadas después la cuestión de los jurados populares para el Distrito Federal fue materia de atención y debate en el Congreso de la Unión. El 28 de diciembre de 1868, el ministro de Justicia e Instrucción Pública envió a ese órgano legislativo un "Proyecto de ley para el establecer en el Distrito el jurado en materia criminal para el Distrito Federal", el cual fue remitido a la primera Comisión de Justicia. El 13 de abril de 1869 se anunció por parte de la secretaría del Congreso que en su sesión del 14 se discutiría dicha iniciativa ante el pleno. La discusión, las enmiendas y correcciones, así como su aprobación final, se efectuó durante el resto de ese mes y gran parte del de mayo, aunque en realidad fue el 29 de abril cuando se pudo constatar que dicha iniciativa sería aprobada por el pleno, sin que faltaran los argumentos en contra, pero no del establecimiento de los jurados populares, sino de algunos de los artículos que se prestaban a confusión o bien que eran cuestionados por lo que pretendían normar. De esta manera, las críticas que se hicieron fueron menos profundas y severas, lo cual se ma-

\footnotetext{
${ }^{31}$ El Siglo $X X X, 28$ de febrero de 1850. Conviene señalar que en octubre de 1850 el Congreso del Estado de México dio entrada y discutió una iniciativa de ley para establecer los jurados populares para juzgar a los ladrones. Ésta no prosperó, pero en cambio sí una que juzgaba a los vagos, entre cuyos apartados se encontraba el jurado popular para conocer de causas por el delito de vagancia. El Monitor Republicano, 25 de octubre de 1850; Colín, Legislación, 1975, pp. 59-70.
}

nifestaría en la aprobación casi unánime que alcanzó la iniciativa en lo general y varios artículos en particular. ${ }^{32}$

Por su parte, el ministro de Justicia explicó que la institución de los jurados populares era motivo de profundas controversias entre quienes exageraban "sus ventajas con verdadero fanatismo" y quienes "la deprimen con apasionado encono". Para Mariscal, el proyecto no tenía la pretensión de ahondar en los pros y en los contras, sino la intención de "ensayar los jurados en el Distrito Federal" y a partir de sus resultados valorar y apreciar, sobre la base de "datos más precisos las objeciones". Así, los jurados en el Distrito Federal ofrecían la oportunidad de conjuntar condiciones especiales que a su vez serían experiencias valiosas para otras entidades que se propusieran establecer este tipo de instituciones, tanto porque el grado de ilustración de su población era mayor que en otras regiones del país como porque podían darse a conocer a la publicidad los debates, despertando el interés "en la masa del pueblo, acostumbrándolo a mirar los fallos como obra suya, porque los dictan individuos sacados de su seno sin requisitos especiales de profesión o ciencia". ${ }^{33}$

De este modo, sería posible despertar el interés del conjunto de la sociedad mexicana por la cosa pública y desterrar la idea equívoca de que el mejor ciudadano era aquel que sólo atendía a su familia y que para nada se mezclaba "en lo que afecta a su comu-

${ }^{32}$ Diario Oficial del Gobierno Supremo de la República, 1 de enero y 16 de abril de 1869.

${ }^{33}$ Diario Oficial, 16 de abril de 1869. 


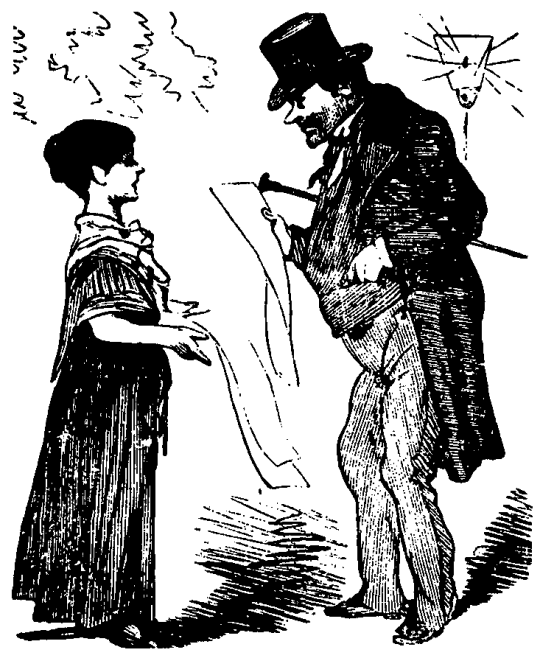

nidad entera, como si nuestros propios intereses pudieran salvarse en medio de la inseguridad y los peligros universales". Y si esta circunstancia era un aspecto muy positivo, no lo era menos que, en términos de la estricta justicia, los jurados asegurarían que los procesos judiciales fueran más breves, pues el proyecto de ley consideraba que los veredictos de los jurados no tendrían que ser revisados, y aun cuando esto sucediera, el juez estaría en la obligación de revisarlos casi inmediatamente al tratarse de una cuestión de derecho y no de hecho, competencia esta última de los jurados, lo que a su vez estaría garantizado por la división que se hacía entre el jurado de hecho y el jurado de derecho. Mariscal estimaba, asimismo, que esta medida modificaría enormemente la práctica y el ejercicio penal y judicial porque, dentro de las facultades que se pensaban introducir en la ley de jurados, estaba que con la presentación de indicios, y no necesariamente con pruebas contundentes - a no ser la confesión de cargos, lo cual llevaba a admitir la aplicación de la tortura para obtenerla, pues era el único instrumento jurídico que tenían en sus manos los jueces-, era posible inferir la responsabilidad de los acusados, modificando en sus cimientos el aparato de justicia. Así, los hábitos judiciales que reproducían los jueces se verían afectados debido a que éstos no estaban acostumbrados a destacar la importancia de los indicios como posibilidad de claridad y convicción moral sobre determinados hechos que podían configurarse como delictivos. Es decir, con estas atribuciones era posible recuperar las pruebas indiciales o circunstanciales, las que evidentemente tendrían efecto enorme en las prácticas judiciales al convertirse en elementos de convicción moral, tal y como sucedía con los testimonios de los testigos, "cuya fuerza probatoria se deriva también de presunciones". ${ }^{34}$

El 29 de abril, el Congreso de la Unión retomó el asunto y aprobó la ley que establecía los juicios por jurados para conocer de delitos comunes. Para su puesta en práctica se dio un plazo de un mes, y no de tres meses como lo proponía el ejecutivo federal, a fin de que adoptaran "todas las providencias necesarias para que quede planteado el juicio por jurados". Finalmente, el 7 de mayo se introdujeron las últimas

${ }^{34}$ Ibid. 
modificaciones a la ley, la cual quedó lista para su promulgación final. ${ }^{35}$

El 15 de junio de 1869 se expidió la Ley sobre Jurados en Materia Criminal para el Distrito Federal y los Territorios, e inmediatamente después varios estados de la república adoptaron esta institución. El ministro de Justicia e Instrucción Pública, Ignacio Mariscal, principal patrocinador de la iniciativa, no dejó de admitir que dicha forma de administrar justicia era una novedad en México, puntualizando que esta institución escasamente se conocía en el país, "donde apenas se conocen los jurados de imprenta, los cuales, por su sencillez y especialidad, se asemejan muy poco a los que ahora se establecen". ${ }^{36}$

Según Mariscal, la ley de jurados tenía el propósito de garantizar una imparcial aplicación de la justicia y evitar la arbitrariedad o discrecionalidad con la que habían actuado los jueces, tal vez no por mala fe, sino por los vacíos jurídicos que existían en la propia administración de justicia. De igual manera, hacía notar que se habian fijado distintas providencias para poner a salvo el prestigio y la imagen del aparato judicial. No obstante, las explicaciones ofrecidas por el ministro de Justicia no fueron suficientes para disipar las dudas y las objeciones que habrian de manifestar algunos sectores de la opinión pública. Acaso, advirtiendo las

${ }^{35}$ Diario Oficial, 17 y 22 de mayo de 1869; "Junio 15 de 1869-Ministerio de Justicia-Ley del Congreso estableciendo el jurado en el Distrito Federal. Ley de Jurados en Materia Criminal para el Distrito Federal" en Dublán y Lozano, Legislación, 1878, t. X, pp. 658-664.

${ }^{36}$ Memoria, 1873, p. 72 .

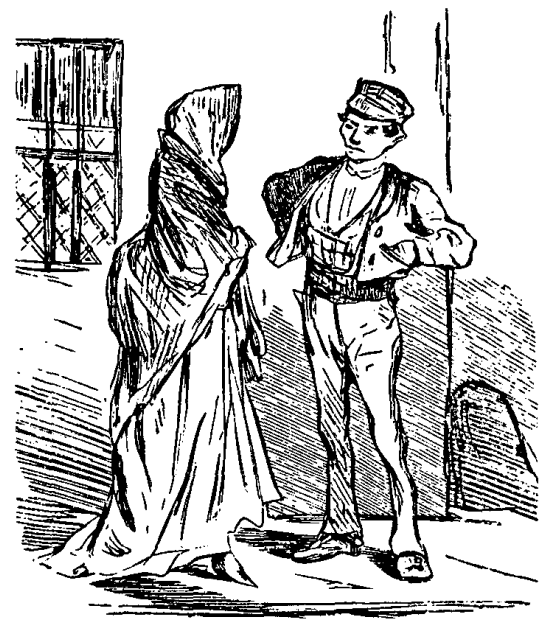

observaciones que se harían al funcionamiento del jurado popular, el ejecutivo federal, en el discurso de clausura del periodo ordinario de sesiones del Congreso, recordó que:

El gobierno ha usado la facultad que le concedió la ley, dictando las reglas que ha creído más oportunas, con objeto de procurar la eficacia de sus disposiciones, a la vez que evitar el abuso de ellas. Ha procurado también que se pongan en acción todos los medios posibles, a fin de que haga menos necesaria la represión severa de los delitos, con el celo más empeñoso para prevenirlos. Sobre una iniciativa del gobierno el Congreso ha discutido y decretado el establecimiento de jurados en el Distrito Federal.

Y manifestaba su deseo de que: "Esta importante mejora [sirva] mucho 
para la buena y pronta administración de justicia." Por su parte, el presidente del Congreso, Francisco Gómez Palacio, en relación con la aprobación de esta ley, señaló que dentro de los logros de esa legislatura destacaba el nivel de consenso que había alcanzado la institución judicial del juicio por jurados, la cual había sido "ardientemente deseada", pero que hasta ese momento no había podido ensayarse "en la porción más importante de la república". ${ }^{37}$

Así, el ejecutivo federal estaba consciente de las enormes dificultades, tanto jurídicas como políticas, que venían aparejadas con la aprobación y aplicación de los jurados populares, pero dispuesto a enfrentarlas y convencido de que sería un aliciente para la sociedad en general y para la administración de justicia en particular. Por lo mismo, el Congreso federal había autorizado que se diera un plazo de tres meses para que entrara en vigor, y el propio ejecutivo tomara una serie de providencias para que los responsables directos de su ejecución, tanto las autoridades políticas municipales de la ciudad de México como los jueces de lo criminal en el Distrito Federal, tuvieran el tiempo necesario para compenetrarse de los alcances y de las facultades que tendrían los jurados populares.

En este sentido, Mariscal era el principal interesado en lograr que la incertidumbre que rodeaba a la nueva institución judicial se disipara, y con este objetivo expidió, poco tiempo después de haberse aprobado esta ley, una ex-

${ }^{37}$ Diario Oficial, 31 de mayo de 1869; La Opinión Nacional, 21 de agosto de 1869. tensa y detallada circular en donde explicaba la manera en que debían proceder los diferentes actores involucrados en la profunda reforma en la administración de justicia. En sí misma, la ley contenía lineamientos audaces al intentar un equilibrio entre los jueces y los jurados, contrarrestando mutuamente las posibilidades de errores en las determinaciones que adoptaran. Mariscal aclaraba una serie de puntos que podrían generar graves confusiones en las tareas encomendadas a los jueces y magistrados, al mismo tiempo que creaba figuras jurídicas fundamentales en la procuración y la administración de justicia.

Entre otros aspectos, puntualizaba que había una modificación en el sentido jurídico de la diligencia conocida como "confesión con cargos" o "la prueba legal", que en realidad operaba como el reconocimiento explícito de culpabilidad del procesado, pero obligaba al juez a levantar una declaración preparatoria, se creaba la figura de los promotores fiscales, quienes se encargarían de presentar las pruebas necesarias para fundamentar su acusación, quitándole al juez esta tarea, evitándo. le ser parte acusadora y enjuiciadora a la vez. La presencia de testigos se reservaba al debate ante el jurado, salvo cuando se temiera la desaparición de éstos.

De esta manera, una vez concluida y cerrada la averiguación, el juez de lo Criminal tenía la obligación de convocar y reunir al jurado, concluyendo con su función de juez de instrucción de la causa, es decir, en su papel de responsable de realizar la averiguación previa. Inmediatamente después de haber con- 
vocado a los miembros del jurado, asumía la función de presidente de debates, "ordenador de la discusión de los testigos con el procesado". También le correspondía formular las preguntas que considerara pertinentes y "sobre las cuales han de votar los miembros del jurado". A su vez, el jurado se limitaba a escuchar el debate y los alegatos de las partes. En este sentido, la tarea del juez era fundamental, porque de él dependía la claridad del juicio, ya que "una pregunta oscura o contradictoria podría viciar el veredicto", y con ello se podía adolecer de "una injusticia irremediable".

En la circular, además, se recomendaba a los jueces y abogados, sin "agraviar la ilustración" de unos y otros, que hicieran explícito el propósito de las preguntas a las cuales tenían que responder los integrantes del jurado popular a fin de determinar si el hecho criminal se había cometido, si el acusado era responsable del mismo y la intencionalidad del acto. En caso afirmativo, entonces podía decirse "con segura conciencia que un procesado es culpable de cualquier hecho criminoso". Aun en el caso en que un procesado fuera declarado culpable por el jurado, el juez tenía que confrontar la resolución del jurado de hecho con el contenido de la ley y determinar si en realidad se trataba de una conducta punible, según las circunstancias agravantes o atenuantes del acto y de acuerdo con las normas penales vigentes, lo que era materia de análisis exclusivamente del juez en su carácter de jurado de derecho. ${ }^{38}$

${ }^{38}$ Diario Oficial, pp. 679-684. "Julio 13 de 1869-Ministerio de Justicia-Circular aclaratoria
De este modo puede apreciarse la importancia y la magnitud de las transformaciones que se intentaban introducir en las prácticas de la administración de justicia. Al menos esa era la impresión que dejaba traslucir el ministro Mariscal, quien hacía notar que:

Como se advierte, si son muy importantes las funciones encomendadas al jurado, no son menos las que quedan reservadas a los jueces de lo criminal, y ellas requieren a más de una alta justificación, las dotes del talento y la ciencia.

Así, ante las objeciones que se levantaron tanto en el Congreso como en una franja importante de la prensa capitalina, el propio ministro de Justicia e Instrucción Pública recordaba las limitaciones de los jurados en las resoluciones judiciales: el juez mantenía las facultades para ordenar la apertura y el desarrollo de las investigaciones, conducía las discusiones y garantizaba el orden de los mismos, sometiendo a los jurados a los procedimientos que consideraba adecuados, negándoles el uso de la palabra, reduciendo su intervención a escuchar y prepararse a discutir entre ellos la averiguación, así como a votar sobre preguntas específicas que les propusiera el juez, quien tenía "la facultad importantísima de fijar las cuestiones sobre las que ha de votar el jurado". 39

Por su parte, la prensa mexicana dedicó gran parte de sus materiales a emi-

de la ley de jurados" en Dublán y Lozano, Legislación, 1878, pp. 679-684.

${ }^{39}$ Memoria, 1873, pp. 82-83. 
tir sus opiniones en torno al funcionamiento de esta institución judicial. En noviembre de 1869, en un largo texto dedicado al análisis de la ley de jurados y publicado en El Monitor Republicano, el abogado Eduardo F. de Arteaga sostuvo, acaso en una conclusión apresurada por el poco tiempo que tenía su aplicación y en contra de "los temores de los pesimistas", que su práctica se había distinguido por el "notable acierto de los ciudadanos que desempeñaban las funciones de jueces de hecho", además de que la simple existencia de ella representaba una "conquista democrática". Para él no había duda de que los veredictos dictados por los jurados populares eran "la expresión genuina de la conciencia y de la justicia", cuyos resultados eran una prueba de un ejercicio democrático del pueblo mexicano, pese a las tergiversaciones que habían querido hacer de ellos "algunos letrados constituidos en autoridad". Arteaga sostenía que los ataques a los juicios por jurados tenían la pretensión de introducir varias modificaciones en su funcionamiento y en sus facultades con el propósito de fortalecer a los jueces de derecho, sobre todo en lo relativo a las objeciones que ponían éstos para dejar inmediatamente en libertad a quienes el jurado había declarado inocentes. Para el jurista, aceptar tales demandas significaba alterar la esencia misma del jurado, pues:

Si necesitara el veredicto absolutorio algo más que su propia resolución, vendría por tierra la base del jurado: la conciencia pública, que es la que allí decide y que no necesita de seguro el apoyo de otro tribunal superior.
Sin embargo, el propio Arteaga matizó sus juicios al aclarar que sin duda era legítimo el temor de la autoridad ante una sentencia absolutoria que estimara errónea, pero esto no podía ser motivo suficiente para "conculcar las disposiciones expresadas en la ley ni para desconocer las justas razones en que se apoyan". Finalmente, ratificaba "el buen sentido del pueblo" y la "escelencia [sic] del criterio público". ${ }^{40}$

Por su parte, en un balance realizado por el periódico $E l$ Derecho, en enero de 1870 , se aseguraba que "en medio de la agitación e inquietud por que ha atravesado la república", la administración de justicia en nuestro país había presentado notables progresos en el año recién concluido: se habían establecido los juicios por jurados en el Distrito Federal, así como en varios estados de la república; estaba por finalizar la redacción del Código Civil y, en fin, se había mejorado "gradualmente la legislación del país". ${ }^{41}$

Conviene destacar que "la agitación e inquietud" que se había vivido en el país había provocado disposiciones penales muy graves, las cuales también dieron paso a una polémica bastante acalorada. Una de esas disposiciones fue la ley contra los plagiarios y salteadores que, entre otras cosas, suspendía los derechos y garantías individuales de quienes hubieran incurrido en la co-

${ }^{40}$ El Monitor Republicano, 26 de noviembre de 1869.

${ }^{41}$ El Derecho, 1 de enero de 1870 . Los estados que adoptaron esta institución judicial fueron, después del Distrito Federal, Sonora, Sinaloa, Jalisco, Guerrero, Campeche, Veracruz, Puebla y San Luis Potosí. 
misión de esos delitos, imponía la pena de muerte contra aquellos que fueran aprehendidos in fraganti, autorizaba a los particulares a organizar partidas armadas para perseguir a los criminales, así como la obligación de los ciudadanos de denunciar a los bandidos a riesgo de ser acusados de complicidad. La vigencia de la suspensión de las garantías individuales se extendió hasta el 10 de abril de 1871.

En este sentido, José Ma. Castillo Velasco expuso las razones que explicaban el fenómeno del bandidaje y sus graves consecuencias para la sociedad, específicamente para un sector de ella: la guerra civil y la inacción, cuyos efectos habían sido que muchos hombres se hubiesen acostumbrado a la vida cómoda y fácil, pues era más agradable vagar por los campos, esquilmar a los hacendados y a los pueblos, amparándose en una "aureola política", antes "que resignarse a ganar laboriosamente la subsistencia con los instrumentos de la industria a mano". De igual modo, para justificar y ubicar los alcances que podía tener la ley, Castillo Velasco se preguntaba

¿Quién ha dicho que una ley por su solo influjo y en el corto espacio de dos meses pueda restablecer la moralidad donde tanto cebo y seducción encuentran los vicios, aun por parte de aquellos llamados a procurar su corrección? ${ }^{42}$

En términos semejantes se expresó el periódico Le Messager Franco-Américain, al sostener que la ley contra los

\footnotetext{
${ }^{42}$ La Opinión Nacional, 14, 16, y 18 de junio de 1869.
}

plagiarios y los salteadores había permitido imponer el orden y formaba parte de varias reformas en materia judicial -incluyendo entre ellas el juicio por jurados- en el Distrito Federal y el estado de Veracruz, el cual, por otra parte, se negó a aplicar la citada ley. Frente a estas voces y opiniones se alzaron algunos periódicos como $\mathrm{El}$ Monitor Republicano, y diversos gobiernos estatales, como el de San Luis Potosí, que expresó su total desacuerdo con la ley por considerar que contenía "actos verdaderamente inconstitucionales y demasiado opresivos para sufrirse", además de representar una violación a la soberanía de los estados. En contraste, uno de los estados que asumió y practicó de inmediato la ley contra los plagiarios y salteadores fue el Estado de México, en donde se ejecutó la pena de muerte contra varios de ellos, además de crearse fuerzas rurales armadas por los hacendados para combatir el bandolerismo y la vagancia que asolaban diversas regiones de la entidad. Según las autoridades, estas medidas habían permitido la disminución de los robos y de los actos criminales en general. ${ }^{43}$

En esta atmósfera social y política, las autoridades políticas pretendieron, con el establecimiento de la institución judicial de los jurados populares, involucrar a la sociedad en un proyecto ambicioso de represión de la delincuencia, a la que percibían como una amenaza real contra la frágil estabilidad del país. Tres años más tarde, desde las páginas de $E l$ Foro, se recapitulaba la trayecto-

${ }^{43}$ Ibid., 30 de abril y 4 de mayo de 1870. 


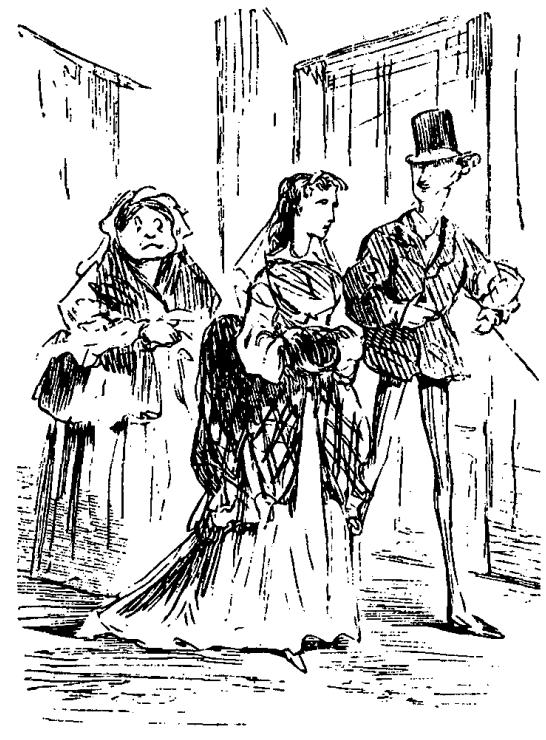

ria que había seguido el juicio por jurados en nuestro país, dentro de un marco de severa crítica al sistema de justicia. Según los redactores, esta "bella institución, la del jurado", era producto "de las viejas costumbres" sajonas, pero las naciones democráticas la habían adoptado en forma natural porque representaba que "la conciencia [fuera] el árbitro supremo de la tierra". Para los redactores del diario, el que nuestro país la hubiera recuperado no significaba necesariamente que diera un salto "a las varoniles costumbres de la libre patria del juicio por jurados". ${ }^{44}$

\footnotetext{
it El Derecbo, 17 de junio de 1873.
}

En opinión de $E l$ Derecho, el juicio por jurados había caído en descrédito por la organización que le había dado la ley, la cual era a todas luces incompleta, como años después habrían de reconocerlo sus defensores. Entre otras cosas, criticaba que se hubiera dejado el veredicto al voto exclusivo de los miembros del jurado, pero se había abandonado la importancia del debate como medio para conformar la opinión de éstos. Además, la idea original de ser un instrumento para la administración de justicia expedita había sido adulterada, pues muchos de los acusados habían pasado varios meses en la cárcel sin que su causa fuera conocida. Los redactores se preguntaban: "¿Quién tiene la culpa?" En primer lugar, puntualizaban, el Código Penal, por sujetar a juicio "a esos delitos casi metafísicos"; en segundo, el juez, por demorar la instrucción del caso y, finalmente, el jurado, "por casualidad, que es aquí como se reúnen los jurados". Era tan deplorable el estado de la justicia que ocurría con frecuencia que las averiguaciones previas se presentaban incompletas y con tal debilidad en las acusaciones que no pocas veces el representante del Ministerio Público reconocía que no había delito que perseguir y, por añadidura, "los jurados se ven las caras y absuelven cabisbajos". Así, era común que en los juzgados se repitieran escenas de esta naturaleza: después de

tanto tiempo perdido para un artesano: la alegría de la libertad desaparecía en el corazón de aquel muchacho con el recuerdo de la cárcel, de la que salía con el instinto maleado quizá por el espectáculo de la vida de nuestras pri- 
siones, y con un amargo sentimiento de aversión a la justicia social. ${ }^{45}$

En contraste con la institución de los jurados populares, las formas más arraigadas de la administración de justicia, que recaía en los tribunales, magistrados y jueces y que tanto se defendía por su supuesta rigurosidad, imparcialidad, objetividad, sentido del deber, responsabilidad e independencia, así como por su conocimiento profundo del derecho, no habían resuelto el problema de la procuración de justicia. Por ejemplo, en 1876 , en una circular expedida por la Sección de Justicia de la Secretaría General del gobierno del Estado de México, se hacia referencia no sólo a "la excesiva benignidad en los jueces" para aplicar las penas a los reos, sino a su afán por buscar los medios para absolverlos "sin ser muy solícitos en inquirir las pruebas convincentes", con el consiguiente descrédito en la aplicación de la justicia y la impunidad de los delincuentes, "dejando herida la vindicta pública y alarma en la sociedad, que mira salir impune de las manos del juez al reo que la vindicta pública designa acaso como el más criminal de los de su comarca". ${ }^{46}$

Algunas de las resistencias a la adopción del jurado popular provinieron no sólo de la prensa, sino también de varios estados. Por ejemplo, el Tribunal Superior de Justicia de San Luis Potosí argumentó en contra del jurado

${ }^{45}$ Ibid., 18 de junio y 4 de julio de 1873 .

${ }^{46}$ Arhivo Histório del Estado de México (en adelante AHEM), c. 25, exp. 7, 1876. "Cuaderno de circulares expedidas por la Sección de Justicia de la Secretaría General de 1878-1876".



popular porque, según sostenía, no tenía antecedentes "ni en nuestras costumbres ni en nuestras instituciones jurídicas", tal y como lo reconocía la circular del 13 de julio que precisaba las funciones y las formas de su integración. Para el Tribunal no se trataba de ninguna conquista del derecho moderno, "sino más bien, uno de los grandes errores, que hay siempre en los extremos a que empuja la revolución producida por el choque de las nuevas contra las antiguas ideas". Agregaba que los jurados populares no eran tampoco producto de las instituciones republicanas, porque

en una democracia donde el poder de juzgar, como de legislar y gobernar, no 
se tienen sino en virtud de elecciones populares, y todos y cada uno de los que ejercen el poder no reciben su investidura de las manos del pueblo, ya de una manera o de otra.

Aunque se cuidaba de indicar que los jueces y magistrados eran nombrados por los ejecutivos estatales, así como del enorme descrédito que rodeaba el ejercicio de la administración de justicia. ${ }^{47}$

Entre 1868 y 1872 se culminaron los trabajos para la elaboración de un Código Penal, que delimitó con claridad los delitos que debían ser castigados y la penalidad que correspondía a cada uno de ellos. La aprobación y puesta en marcha del Código Penal se estimó como la síntesis de una "legislación sabia" porque recogía "todos los [códigos] existentes en ambos hemisferios", habiéndolos ajustado "a las necesidades, costumbres, carácter y forma de gobierno del pueblo mexicano".

Así, en medio de la prolongada crisis social y de administración de justicia en México, la práctica de los juicios por jurados estaría sujeta a una meticulosa evaluación de su utilidad e importancia como un mecanismo de educación para la democracia, así como de los beneficios que arrojaba su funcionamiento como contrapeso de las facultades otorgadas a las otras instancias judiciales. Precisamente con base en esa evaluación, formulada desde los círculos judiciales y políticos cercanos a las autoridades, se introdujeron importantes modificaciones no sólo a

\footnotetext{
${ }^{47}$ Sodi, Jurado, 1909, pp. 46-47.
}

su funcionamiento interno, sino al tipo de delitos sobre los que debía pronunciarse.

En 1880 , el ministro de Justicia e Instrucción Pública, Ezequiel Montes, después de admitir que no había sido suficiente "la reforma en codificación, ni las distintas organizaciones que se han dado a los tribunales", se había dado a la tarea de proponer reformas sustanciales a la administración de justicia, "ante el clamor público, y sobre todo las frecuentes quejas de la prensa". Sin duda alguna, el informe que presentó el ministro de Justicia al titular del ejecutivo federal sobre el estado que guardaba la organización y funcionamiento de los tribunales, de acuerdo con las facultades que le había conferido el Congreso de la Unión, fue bastante severo, a tal grado que denunció las resistencias de los integrantes de los tribunales e insinuó que "esto podría interpretarse en el público como un pretexto para ganar tiempo, en cuyo espacio se pudieran reparar los defectos y lagunas que hubiera en los archivos", y agregó que confundía "de una manera lastimosa la independencia de los tribunales, con la impunidad de los jueces omisos, torpes o prevaricadores", en especial el del Tribunal Superior de Justicia del Distrito Federal, que se negó inicialmente a aceptar una revisión de su actuación alegando, con justificación, que ello era una intromisión de un poder ajeno al judicial. ${ }^{48}$

De igual manera, acaso aprovechando la oportunidad que se presentó para

\footnotetext{
${ }^{48}$ Montes, Memoria, 1881, Apéndice 3, pp. $9-14$
} 
introducir modificaciones al sistema de administración de justicia, se hizo referencia al funcionamiento de los jurados populares. Precisamente, el Tribunal Superior de Justicia del Distrito Federal propuso una serie de cambios que afectaban directamente la integración y el funcionamiento de los jurados, atendiendo "la voz de la prensa y la del público en sus clases más ilustradas" ${ }^{9}$ Entre las voces que se alzaron estaba la del propio Ignacio Mariscal, quien aseguraba estar convencido "más que nadie de la urgencia de reformar la Ley de Jurados, aprovechando las lecciones de la experiencia" y "antes de llegar a la triste conclusión de que el pueblo de esta capital no tiene por ahora el grado de cultura o de morales indispensables para el jurado". No obstante, Mariscal sostenía, en contra de quienes opinaban que era necesario suspender los juicios por jurados $y$ aun eliminarlos en forma definitiva como una mecanismo de impartir justicia, entre los que se incluían "no sólo personas de juicio y buena fe, sino también enemigos sistemáticos", la inconveniencia de suspenderlos, porque en la práctica significaba su desaparición. Además, el ex ministro de Justicia agregaba que mientras no se aprobara el Código de Procedimientos Penales se seguirían presentado errores y prácticas indeseables no sólo en los juicios por jurados, sino en toda la administración de justicia. ${ }^{50}$

El alegato central del Tribunal del Distrito Federal fue muy similar al utilizado por la Secretaría de Justicia para

${ }^{49} \mathrm{Ibid}$., Documento 42 , pp. 37-38.

s0 Ibid., Documento 43, pp. 38-40. vigilar las labores de los tribunales, es decir, que

muchos de los veredictos pronunciados últimamente, absolviendo a reos convictos $y$ aun confesos de los delitos por que fueron procesados, ha causado grande alarma en la sociedad, y que esta alarma es justísima, porque tales veredictos alientan a los criminales con el ejemplo de la impunidad, propagan y desarrollan en el pueblo el sentimiento de inmoralidad y dan lugar a apreciaciones erróneas, cuyo resultado pudiera ser el de destruir la institución jurado que es tan importante, porque da al pueblo parte en el gobierno de sí mismo.

Aunque admitía cierta responsabilidad de los funcionarios judiciales en las prácticas viciosas que se habían originado en esa institución. De hecho, los miembros del Tribunal Superior de Justicia del Distrito Federal recomendaban la suspensión de los juicios por jurados hasta en tanto no se aprobaran las reformas que creían necesarias, particularmente en la forma de integrar las listas de los jurados y la manera de seleccionarlos,

citando a un número de ciudadanos, de entre los cuales se elijan en el acto a los que hayan de formar el jurado, para evitar en lo posible el abuso de las influencias y las seducciones de todo género que suelen ponerse en juego por quienes se empeñan, sin consideración ninguna a la sociedad, en salvar a los criminales. ${ }^{51}$

Entre las reformas que se hicieron al juicio por jurados, mediante la expedición del Código de Procedimientos

${ }^{51} \mathrm{Ibid}$., Documento 42, p. 38. 
Penales, estaba la posibilidad de seleccionar a un "mayor número y mejor clase de personas" al permitir que los empleados públicos pudieran formar parte de las listas, pues representaban "un grupo considerable de individuos a propósito para esas funciones"; exigir que quienes las componían contaran con un peso diario "ganado de cualquiera ocupación honesta", garantizando con ello la inclusión de las clases trabajadoras "dotadas de la aptitud indispensable"; fijar reglas claras a fin de evitar que las personas acomodadas evadieran esa responsabilidad ciudadana, y realizar las insaculaciones hasta el inicio de la audiencia para los debates para conocer quiénes eran los jurados definitivos, "alejándose la posibilidad de seducción o soborno".

Asimismo, se facultaba a los jueces para presentar un resumen imparcial de los alegatos ofrecidos por la parte acusadora y la acusada a fin de que no fueran "los argumentos tal vez alucinadores de una de ellas, sino la enunciación, por una voz desapasionada, del pro y contra de la cuestión que va a resolverse". Finalmente, el veredicto rendido por el jurado, para tener validez, tenía que contar con el voto de al menos nueve de los once jurados. En caso contrario, el juez estaba facultado para enviarlo a la Sala de Casaciones para su revisión y sentencia. Al mismo tiempo, se estableció un jurado de responsabilidades con la encomienda de juzgar a aquellos magistrados del Tribunal Superior del Distrito que hubieran incurrido en delitos oficiales y con ello garantizar la imparcial aplicación de la justicia, pues hasta ese momento no había ninguna instancia que cono- ciera de los delitos éstos, lo cual representaba una "monstruosa anomalía". 52

Una década después, el Congreso de la Unión autorizó al ejecutivo a reformar el Código de Procedimientos Penales del Distrito Federal y territorios de la Baja California y de Tepic. La petición hecha por el ejecutivo tenía el propósito de modificar la parte correspondiente al funcionamiento y la integración del juicio por jurado, y para tal efecto nombró una comisión de tres miembros, Rafael Rebollar, F. G. Puente y P. Miranda. El 24 de junio de 1891, dicha comisión presentó ante el secretario de Justicia, Joaquín Baranda, la parte expositiva de las reformas que se proponían al código y a la Ley de Jurados, de las razones que las fundamentaban, del sentido de cada una de ellas y de la necesidad de introducirlas en la legislación penal, atendiendo a "las necesidades sociales y a llenar las exigencias general y públicamente manifestadas". Admitía que se trataba de reformas "audaces", sobre todo porque había quienes criticaban el poco tiempo que había transcurrido entre las innovaciones introducidas y las que se proyectaban y "so pretexto de que la práctica, por medio de los encargados de hacerlas efectivas, puede ir haciendo que se disminuyan o desaparezcan", es decir, los funcionarios judiciales. En contra de esta opinión, la comisión señalaba que no era posible que el "vicio, la arbitrariedad y el criterio desigual" de esos funcionarios pudieran resarcir los vacíos que se iban presentando en la práctica de la administración de justicia, y menos aún pensar

${ }^{52}$ Ibid., Documento 48, pp. 61-63. 
que "son buenas las leyes defectuosas y que no deben corregirse". En suma, los comisionados estaban persuadidos, tras diez años de estar interpretando y aplicando sus disposiciones, así como el Ministerio Público, la judicatura y la magistratura, "ora de la necesidad, ora de la conveniencia de las reformas que el gobierno desea, a que el público aspira". 53

Más adelante puntualizaban cada una de las reformas que proponían y que al final fueron aprobadas aunque entraron en vigencia hasta 1894. Entre ellas estaba reducir el número de miembros del "tribunal popular" de once a nueve, con el fin de garantizar "las calidades necesarias para desempeñar el cargo de jurado", tales como ilustración e independencia, las cuales eran indispensables para mantener el prestigio de la institución y el acierto de las decisiones. Ello, según la comisión, se aseguraba con el requisito de que los jurados fueran profesores titulados o tuvieran un sueldo, renta o utilidad "de cualquiera procedencia honrada" cuando menos de cien pesos, que a su vez excluía "cierto tipo de notoria ineptitud o que se perjudica considerablemente, y a hacer que se ensanche por otro lado el círculo de los que pueden escogerse para que figuren en las listas", e incluía a los hombres de 21 años, cuando la anterior ley exigía haber cumplido 25. Asimismo, hacía más expedito el mecanismo para decidir sobre las peticiones de aquellos que alegaban no poder cumplir con la encomienda ciudadana al otorgarle al juez de lo criminal la facultad de calificar y

${ }^{53}$ Memoria, 1892, Documento 46, pp. 62-63. resolver las solicitudes en tal sentido, restándole al gobernador del Distrito esa obligación. ${ }^{54}$

Al mismo tiempo, se introdujeron distintas medidas para tener un mayor control sobre el proceso mismo de la averiguación penal, obligando a las partes, tanto a la defensa como a la acusadora, a presentar en un menor tiempo el resultado de sus indagatorias, así como sus conclusiones, las cuales una vez hechas públicas no podían retirarse o añadirle otras y cuyo objetivo era impedir el alargamiento innecesario de los juicios, ya fuera una estrategia de la defensa del presunto delincuente o una petición del Ministerio Público, lo que propiciaba que los juicios fueran prácticamente interminables. Como puede apreciarse, estos cambios procuraban corregir las deficiencias no de las "calidades" de ilustración e independencia de los jurados, sino del procedimiento general del juicio por jurados. Es decir, contra la opinión de una gran cantidad de magistrados y jueces y aun de la prensa que atacaban esta institución por los veredictos "escandalosos" de los jurados, el problema residía en gran medida en las formas poco claras de proceder de los funcionarios judiciales y de las confusiones que la misma Ley de Jurados propiciaba. De este modo se facultaba tanto al Ministerio Público como a la defensa para que clasificaran y tipificaran, en el momento mismo del juicio, los hechos presentados, de tal manera que se pudiera configurar un delito diverso al presentado originalmente. Esto podía hacerse mediante la

${ }^{54}$ Ibid., Documento 46, pp. 63-64. 


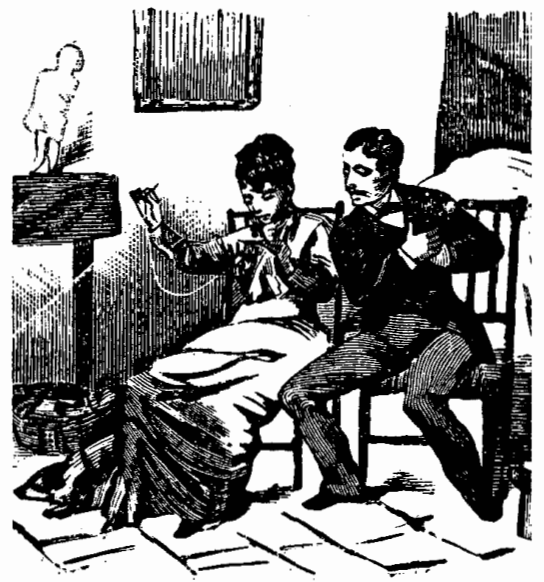

formulación de dos interrogatorios, uno presentado por el Ministerio Público y otro por la defensa, entre los que decidía el jurado cuál de ellos debía someterse a votación. Para la comisión, esta previsión evitaría el "absurdo de que el jurado votase la absolución cuando estaba convencido de la culpabilidad".

Otro punto de interés especial fue el relativo a la importancia de incluir a los peritos científicos como una figura auxiliar dentro de la formación del proceso, evitando que el jurado conociera de preguntas de naturaleza científica, en especial los relacionados con cuestiones psiquiátricas tales como la responsabilidad de los delincuentes que eran víctimas de la demencia o "grandes neurosis", "dada su incompetencia de improvisar una opinión decisiva en una audiencia, en la que no es posible el recogimiento ni la aprecia- ción del valor de los elementos puramente científicos y fuera de su alcance". En el mismo sentido y por las mismas razones, se prohibió que en la presentación de la requisitoria y la defensa se citaran leyes, doctrina y autores para evitar que se influyera en los jurados, "en vez de hacerlo conforme a su conciencia, que es como está establecido en todas las legislaciones". En cambio, se facilitaba la labor de las partes al admitir que ambas podían destacar ciertos hechos y circunstancias de acuerdo con los intereses que representaban y dar a conocer los efectos legales que podían acompañar el veredicto de los jurados, precaviéndolos contra el horror de una sentencia mal dictada.

De ahí que los miembros de la comisión hubieran atendido las voces "de personas de diversas condiciones sociales" para que la primera pregunta que se pusiera en el cuestionario, el cual servía de base para decretar el veredicto, no fuera la relativa a la culpabilidad del acusado, sino que hiciera referencia a los elementos materiales del hecho y así tener mayor claridad en la decisión que fueran a adoptar. Sin embargo, no estimaron oportuna esta petición, pero dio ocasión para exponer su visión sobre lo que significaba la esencia de la institución, tanto en términos filosóficos cuanto de derecho penal, al argumentar que esa medida atentaba contra su sustancia, en tanto que:

El principio democrático en que el jurado se funda consiste en que los miembros de la sociedad que se han apartado o han quebrantado las leyes penales establecidas para la seguridad común, 
sean juzgados por sus iguales como más idóneos para decidir si la acción infractora es punible, si el elemento moral, psíquico y voluntario intervino y debe ser objeto de represión. Pues bien, equé quedaría de todo eso si al jurado se le preguntasen únicamente hechos materiales? Nada absolutamente, supuesto que el delito consiste en la infracción voluntaria de la ley penal. El elemento, pues, de la voluntad o de que el acto se ejecute a sabiendas, es el que da la moralidad, la imputabilidad de la acción bumana, que es la que se somete al jurado, y ésta es la que está comprendida en la palabra culpabilidad. No todo hecho que causa perjuicio o con el que se infringe la ley penal implica responsabilidad en el agente. ${ }^{55}$

Estas reformas no fueron las únicas en la historia del juicio por jurados. El 17 de diciembre de 1902, mediante la expedición de la Ley de Organización Judicial, se instituyeron tres jueces presidentes de debates, a quienes correspondería llevar a jurado las causas por delitos cometidos en el Distrito Federal y cuyas penas excedieran de dos años de prisión. Esta ley restó un gran número de facultades al jurado, "mas no fue el último golpe que sufrió la institución", pues en diciembre de 1907 se estipuló que éstos sólo conocerían de los delitos del fuero común con penas superiores a seis años de prisión por término medio. Para Demetrio Sodi, era claro el sentido de las reformas: "cercenarle al jurado sus atribuciones, hasta dejarlo reducido a su mínima expresión". En la práctica se trató de impedir que la sociedad quedara sin posi-

$$
\text { ss Ibid., Documento 46, pp. 65-69. }
$$

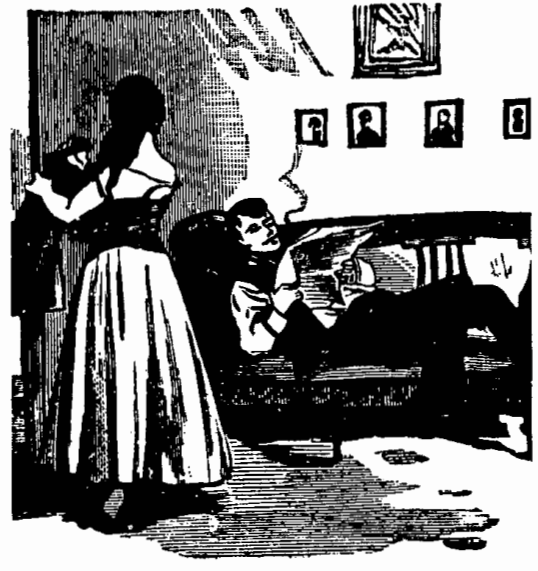

bilidad de intervenir directamente en la administración de justicia. ${ }^{56}$

En este marco, los enormes desafíos que representaba la propuesta de establecer los jurados populares, así como los obstáculos para su funcionamiento regular, los cuales provinieron de diferentes sectores de la sociedad, eran evidentes.

\section{UN JUICIO FINAL}

Vale la pena destacar la opinión de uno de los más firmes defensores de la institución judicial de los juicios por jurados, Federico Sodi, quien después de varios años de estar involucrado en las prácticas de los jurados populares, hizo un recuento de las virtudes y los defectos que la acompañaban y reba-

${ }^{56}$ Sodi, Jurado, 1909, pp. 43-45. 
tió los argumentos con que se justificó su virtual desaparición. De estos últimos, señaló que eran falsas las imputaciones acerca de su venalidad y su conversión en una "máquina absolvedora" de criminales. De la primera acusación, admitía que era posible que se hubieran presentado casos en que los jurados populares hubieran puesto "a remate su voto", pero esa conducta tenía un límite, que era precisamente los defensores que no osaban arriesgar todo su prestigio por un éxito fugaz, prestándose a corromper a los jueces populares con dádivas, sobre todo porque los jurados tomaban "muy en serio y muy honestamente su función de jueces". Por lo que respecta a la segunda, también reconocía que hubo casos en que aun estando convencidos de la culpabilidad del acusado, éste fue absuelto por los jurados al considerar que el delito cometido no guardaba proporción con la pena a la que era acreedor, pues les parecía excesiva. De ahí que el juicio por jurados era "un termómetro de la moral social del momento". 57

En esta dirección, Sodi puntualizaba que el juicio ante el tribunal tenía un efecto pedagógico, no sólo por la seducción que provocaba entre los asistentes, testigos y protagonistas, presenciar "un espectáculo atractivo", sino por el despliegue de recursos para poner al descubierto las pasiones, las creencias, los hábitos, las costumbres arraigadas, los motivos y las razones, en suma, el "corazón humano", creándose una atmósfera que hacía brotar lentamente la verdad. Esas voliciones

${ }^{57}$ Sodi, Jurado, 1961, pp. 27-28. sociales a las que hacía referencia Pallares, se hacían manifiestas en los jurados populares, y la observación meticulosa de Sodi representa un testimonio fundamental para comprender la importancia y el significado que tenían los jurados populares:

Un caso se ganaba o se perdía a través de las pruebas que ponían a la vista de los jueces del pueblo a través de los interrogatorios al procesado, a los testigos, a los peritos del caso: El instinto del jurado le hacía distinguir la verdad de la mentira con una precisión matemática; una respuesta sencilla y clara, una mirada serena del testigo, un gesto, un temblor de manos, una actitud agresiva contra alguna de las partes contendientes, operaban sobre la mente del juez popular para descubrir quién estaba diciendo la verdad o quién estaba mintiendo; todo por un maravilloso fenómeno intuitivo. ${ }^{38}$

De esta manera, la instauración y la vigencia de la institución judicial del juicio por jurados, en particular la que se estableció en 1869 para conocer de delitos comunes en el Distrito Federal, formó parte de un proceso de transición, quizá todavía inconcluso, más amplio, múltiple y diverso, y que envolvió al sistema de administración, heredado del antiguo régimen colonial, con su penalidad y sus modos y prácticas judiciales, hacia uno moderno, racional y doctrinario, que se inauguró con la promulgación del código penal de 1871. El largo y nunca resuelto debate acerca del juicio por jurados, así como las experiencias derivadas de su

${ }^{58}$ Ibid., p. 24. 
ejercicio y aplicación, ilustran fragmentos de estas transformaciones en las instituciones judiciales y penales de nuestro país. En cualquier caso, es necesario profundizar en el conocimiento de hasta dónde llegó esta institución, de cómo influyó en la jurisprudencia judicial y penal, de la doctrina y de las normas de los órganos encargados de impartir la justicia, de cómo y bajo qué circunstancias los tribunales y los jueces modificaron sus hábitos, prácticas, valores, creencias y maneras de ejercitar la justicia. De igual modo, está pendiente la respuesta a la pregunta que lanzó Federico Sodi al momento de declararse virtualmente extinta esta institución: “iEs mejor (la justicia docta, serena, fría y ponderada de los jueces de derecho) que la justicia del jurado popular, o no es mejor que aquella justicia?" El propio Sodi cedió a su impulso esbozando una posible respuesta:

Digamos que es tan mala o que es tan buena. Las mismas absoluciones escandalosas y las mismas condenaciones de las que el público no se entera, y cuando se entera no cree en que sean definitivas, sino que se ahogarán en la corriente de los recursos judiciales. 59

\section{ARCHIVOS}

-AHEM Archivo Histórico del Estado de México.

\section{HEMEROGRAFÍA}

-El Derecho, México, D. F. -El Foro, México, D. F.

${ }^{59}$ Ibid., p. 311.
-Diario Oficial del Gobierno Supremo de la República, México.

-El Monitor Republicano, México, D. F. -La Opinión Nacional, México, D. F. -El Siglo XIX, México, D. F.

\section{BIBLIOGRAFÍA}

-Arnold, Linda, Burocracia y burócratas en México, 1742-1835, Consejo Nacional para la Cultura y las Artes/Editorial Grijalbo, México, 1991.

-Colín Sánchez, Guillermo, Legislación penal del Estado de México, Biblioteca Enciclopédica del Estado de México, México, 1975, t. 1.

-Díaz de León, Marco Antonio, Diccionario de derecho procesal penal, Editorial Porrúa, México, 1986, tomo 1.

-Guenot, Estevan, Plan de educación elemental y de varios establecimientos de utilidad pública y de beneficencia, que somete a la aprobación de las Cámaras de la república mexicana, Imprenta del ciudadano Alejandro Valdés, México, abril de 1826.

-"Informe de la Suprema Corte de Justicia de los Estados Unidos Mexicanos, en que se proponen varias medidas para el arreglo de la administración de Justicia. México 6 de abril de 1833" en Lucio Cabrera Acevedo y Linda Arnold, La Suprema Corte de Justicia. Sus origenes y primeros años, 1808-1847 (Apéndice documental), Suprema Corte de Justicia de la Nación, México, 1986.

-Jonama, Santiago, De la prueba de los jurados o sea consejo de bombres, reimpreso en la oficina a cargo de Rivera, México, 1824.

-Legislación mexicana o sea Colección completa de las leyes, decretos y circulares que se ban expedido desde la consumación de la independencia, tomo que comprende de enero a diciembre de 1855 , Imprenta de Juan Navarro, México, 1855. 
-Legislación mexicana o Colección completa de las disposiciones legislativas expedidas desde la independencia de la república ordenada por los licenciados Manuel Dublán y José Maria Lozano, edición oficial, Imprenta del Comercio de Dublán y Chávez a cargo de M. Lara (hijo), México, 1878, tomo $\mathrm{x}$.

- Memoria que el encargado de la Secretaría de Justicia e Instrucción Pública presenta al Congreso de la Unión en 15 de septiembre de 1873, cumpliendo con lo prevenido en el artículo 89 de la Constitución. Imprenta del Gobierno, México, 1873.

-Memoria que presentó el secretario de Estado y Despacbo de Justicia e Instrucción Pública, Joaquín Baranda. Diciembre de 1888-diciembre de 1892, Imprenta del Gobierno, México, 1892.

-Montes, Ezequiel, Memoria que presenta el secretario de Justicia e Instrucción Pública al Congreso de la Unión y comprende del 1 de enero de 1878 al 15 de septiembre de 1881, Tipografia Literaria de F. Mata, México, 1881.

-Mora, José Ma. Luis, "Disertación formada y leida por don... ante el Supremo Tribunal de Justicia del Estado de México para examinarse de abogado, sobre las cuestiones siguientes: ¿Cuáles son las ventajas que han resultado al Estado de México de las variaciones hechas en su Constitución, así sobre el orden de los juicios como el de los tribunales?" en Obras completas, José Maria Luis Mora, vol. II, Obra política (investigación, recopilación, selección y notas Lilián Briseño Senosiáin, Laura Solares Robles y Laura Suárez de la Torre),
México, SEP/Instituto de Investigaciones Dr. José María Luis Mora, 1986.

-Ovalle Favela, José, "Los antecedentes del jurado popular en México" en Estudios de derecho procesal, UNAM, México,1981.

-Padilla Arroyo, Antonio, "Criminalidad, cárceles y sistema penitenciario en México, 1876-1910", tesis de doctorado en historia, Centro de Estudios Históricos-El Colegio de México, México, 1995.

-Pallares, Eduardo, Reformas urgentes en la administración de justicia, Imp. de José Ignacio Durán y Cía., México, 1912.

-Sodi, Demetrio, El jurado en México. Estudios sobre el jurado popular, Imprenta y Fototipia de la Secretaría de Fomento, México, 1909.

-Sodi, Federico, Memorias, Oasis, México, 1961.

-Urías Horcasitas, Beatriz, "De la justicia a la ley: individuo y criminalidad en el México independiente, 1821-1871", Revista de Investigaciones Juridicas, Escuela Libre de Derecho, núm. 21, 1997, pp. 623-688, México.

-Zarco, Francisco, Historia del Congreso Extraordinario Constituyente de 1856 y 1857. Extracto de todas las sesiones y documentos parlamentarios de la época por..., Imprenta de Ignacio Cumplido, México, 1857 , tomo 1 .

Crónica del Congreso Extraordinario Constituyente (1856-1857), El Colegio de México, México, 1957.

-Zavala, Lorenzo de, Ensayo bistórico de las revoluciones en México desde 1808 basta 1830, FCE/Instituto Cultural Helénico, México, 1985. 